\title{
Role of ADAMTS-1 in Pleomorphic Xanthoastrocytoma Tumor Cells Progression
}

\author{
Aysun GOKCE 1 , Emre Cemal GOKCE², Asuman SUNGUROGLU ${ }^{3}$ \\ ${ }^{1}$ University of Health Sciences, Diskapi Yildirim Beyazit Training and Research Hospital, Department of Pathology, Ankara, Turkey \\ ${ }^{2}$ University of Health Sciences, Ankara Oncology Training and Research Hospital, Department of Neurosurgery, Ankara, Turkey \\ ${ }^{3}$ School of Medicine, Ankara University, Department of Medical Biology, Ankara, Turkey \\ This study has been presented as an poster presentation at the $30^{\text {th }}$ Scientific Congress of Turkish Neurosurgery Society between 9-12 April 2016 at \\ Antalya, Turkey.
}

Corresponding author: Aysun GOKCE aysungokce80@yahoo.com.tr

\section{ABSTRACT}

AIM: To analyze the expression of ADAMTS-1, NF-KB, and STAT3 in human pleomorphic xanthoastrocytoma specimens, and their correlation with glioma advancement.

MATERIAL and METHODS: Pleomorphic xanthoastrocytoma tumor cell lines were treated with low and high doses of cytokines at 24 and 48 hours $(h)$ to replicate the inflammatory environment. The effects of IL-1 were assessed with the scratch wound-healing assay, and the expression levels of ADAMTS-1, NF-KB, and STAT3 of the groups were determined by western blot analysis.

RESULTS: Cytokine treatment significantly increased the migration of PXA glioma cells after scratching at $24 \mathrm{~h}$ and $48 \mathrm{~h}$ time points. Similarly, 10 and $30 \mathrm{ng} / \mathrm{mL} \mathrm{IL}-1$ induced 1.86 and 1.94 fold increases, respectively, in ADAMTS-1 expression after 24h, and 3 and 3.27 fold increases, respectively, after $48 \mathrm{~h}$, compared with the non-treatment control group. 10 and $30 \mathrm{ng} / \mathrm{mL}$ IL-1 doses caused 2.5 and 2.6 fold increase, in NF-kB protein levels after $24 \mathrm{~h}$, and 3.16 and 3.41 fold increases after $48 \mathrm{~h}$, compared with the non-treatment group. The protein levels of STAT3 after $24 \mathrm{~h}$ were 2.62 and 2.43 fold higher, and 3.78 and 3.84 fold higher after 48 hours, with 10 and $30 \mathrm{ng} / \mathrm{mL} \mathrm{IL}-1$, compared with the non-treatment group.

CONCLUSION: The proliferation and progression of glioma cells were proportional to the increased expression levels of ADAMTS-1, $\mathrm{NF}-\mathrm{KB}$, and STAT3. Our findings indicate that the proteolytic function of ADAMTS-1 may be associated with the malignant transformation of low-grade gliomas.

KEYWORDS: Pleomorphic Xanthoastrocytoma, Matrix Metalloproteases, NF-kappa B, STAT3 transcription factor, Glioma

ABBREVIATIONS: ADAMTS: A disintegrin and metalloproteinase with thrombospondin motif, ECM: Extracellular matrix, GBM: Glioblastome multiforme, IGFBP-2: Insulin-like Growth Factor Binding Protein 2, IL-1: interleukin-1, NF-kB: Nuclear Factor-kappa B, PXA: Pleomorphic xanthoastrocytoma, STAT3: Signal transducer and activator of transcription 3

\section{INTRODUCTION}

$\mathrm{G}$ lioma cells attain migratory and invasive properties early in tumorigenesis due to uncontrolled atypical processes, including cell proliferation, cell invasion, extracellular matrix (ECM) remodeling, migration, and the establishment of vascular supply (10). Among these processes, post-translational modifications to the ECM structure complex caused by alterations in protease expression have been strongly associated with tumor progression (57).

PXA is a relatively rare low-grade brain tumour, with a $30 \%$ recurrence and $75-80 \%$ overall survival rates following surgical removal (39). PXA has lack of genetic properties which are characteristics of infiltrative gliomas (19). PXA has a favorable prognosis, but cases showing mitoses more 
than five per 10 high-power field with or without necrosis are termed 'anaplastic PXA'. Cases with signs of anaplasia have poor prognosis, and the tumors' clinical behavior can be more aggressive. A previous study reported that a high mitotic index is associated with increase in recurrence and decrease in overall survival (9). The mitogen-activated protein kinase/ extracellular signal-regulated kinase signaling pathway may lead to the promotion of cell proliferation and differentiation, and thus may increase the invasion and migration of PXA. However, its rarity and the lack of knowledge about the natural clinical course of PXA tumor cells hinder advances in defining the factors that predispose these cells to the acquisition of anaplastic features.

ADAMTS family of 19 identified metalloproteases have been widely involved in cancer development and tumor progression through the degradation and polymerization of structural ECM proteins. ADAMTS-1 is the member of these matelloproteases with a molecular structure characterized by domains, modules, and motifs. The signal peptide, prodomain, metalloproteinase, and disintegrin domains constitute the amino half of ADAMTS proteases ( $\mathrm{N}$-terminal), whereas the carboxyl region (C-terminal) consists of the cysteine-rich domain, spacer region, and thrombospondin type 1 motif. The metalloprotease and disintegrin-like domains of ADAMTS-1 catalyze the breakdown of versican and aggrecan, which are known to be the components of $\operatorname{ECM}(45,46)$. The binding ability of ADAMTS-1 to the ECM is attributed to its C-terminal thrombospondin motifs (21). The lectican family forms a lattice structure in normal adult brains by linking to hyaluronan and tenascin-R. Aggrecan and brevican are proteoglycans of the lectican family, which are essential for maintaining the integrity of the brain ECM (59). The proteases remodel the host tissue environment, precipitate new blood vessels formation, and facilitate glioma progression through proteolytic ECM degradation. In addition to the remodeling of the ECM, inflammation is another important process to be involved in tumor development, from initiation to metastatic progression (12). Initially, ADAMTS-1 was identified as an intermediator of inflammation in an experimental model of colon carcinoma (23). Several studies have reported increased expression levels of ADAMTS-1 after IL-1 administration, which suggests that ADAMTS-1 production could be up-regulated by inflammatory mediators and cytokines $(14,20,51)$. The effect of ADAMTS-1 on tumor invasion and the development of inflammation related cancer could be directly due to its proteolytic activity $(7,24,35)$.

Nuclear Factor-kappa B (NF-kB) and Signal Transducer and Activator of Transcription 3 (STAT3) are transcription factors linking inflammation to cancer development. Both are critical regulators that contribute to the process of tumorigenesis through interaction with immune and inflammatory functions (41). NF-KB is abnormally regulated in glioblastoma multiforme (GBM), in which translocation of the phosphorylated form of NF$\mathrm{KB}$ into the nucleus plays a critical role in tumor cell proliferation (34). Furthermore, STAT3 is commonly activated in several cancers $(4,11,60)$. The tyrosine and serine phosphorylation status of STAT3 has been determined to be constitutively active (27). Levels of activated STAT3 are elevated in high- grade gliomas and are reported to be positively associated with tumor grade $(1,3)$. Moreover, McFarland et al. analyzed these transcription factors in primary human GBM xenografts and cultured GBM cell lines and reported that inhibiting the activity of NF-KB and STAT3 causes a decline in glioma size and aggressiveness (33).

The expression of ADAMTS-1 in pleomorphic xanthoastrocytoma (PXA) tumors has not yet been reported. It is therefore of interest to investigate whether ADAMTS- 1 is involved in the cytokine-mediated invasion and progression of PXA. Herein, PXA cell lines were treated with different cytokine doses. Development and progression of PXA associated with the activity of ADAMTS-1, NF-kB and STAT3 were examined under the replicated inflammatory conditions in this in vitro model.

\section{MATERIAL and METHODS}

\section{Cell Cultures and IL-1 Cytokine Treatment}

The human PXA tumor primary cell line was kindly supplied by Ankara University. The cell lines were originally isolated from astrocytic tumors that were diagnosed as PXA. Dulbecco's Modified Eagle Medium (DMEM) and $4.5 \mathrm{~g} / \mathrm{L}$ Glucose (Lonza), $10 \%$ fetal bovine serum, $\% 1 \mathrm{~L}$-glutamine, $100 \mathrm{U} / \mathrm{mL}$ penicillin, and $100 \mathrm{U} / \mathrm{mL}$ streptomycin were used to culture the cells in a $5 \% \mathrm{CO}_{2}$-humidified atmosphere at $37^{\circ} \mathrm{C}$. Incubation of the $1.0 \times 10^{5} / \mathrm{mL}$ cell density were supplied with low-dose (10 $\mathrm{ng} / \mathrm{mL}$ ), and high-dose (30 ng/mL) IL-1 for 24 and 48 hours. Afterwards, cells harvest and isolation of proteins were achieved.

\section{In Vitro Wounding Migration Assay}

PXA tumor primary cells were seeded in 6-well culture plates until confluent and left overnight. The next day culture medium was removed, and a pipette with a tip of $200 \mu \mathrm{L}$ was used to draw across the diameter of each well. To wash the cells, PBS was added in an incubator at $37{ }^{\circ} \mathrm{C}$ and $5 \% \mathrm{CO}_{2}$. After scratching, cells in medium with $\% 1 \mathrm{FBS}$ were cultured and treated with doses of $0 \mathrm{ng} / \mathrm{mL}, 10 \mathrm{ng} / \mathrm{mL}$, and $30 \mathrm{ng} / \mathrm{mL} \mathrm{IL} 1$. Wound closure was observed, and cells in the scratched area were counted and photographed under an optical microscope at 40x magnification after 24 and 48 hours

Cell-free areas of the representative images from the woundhealing assay were evaluated using the Wimscratch platform. Data represent three replications, and were analyzed using Student's t-test.

\section{Cell Protein Extraction}

After the different treatments, phosphate-buffered saline was used to wash the cells which then tyrpsinized from the plates. Cells $\left(3 \times 10^{6}\right)$ were solubilized in $1485 \mu \mathrm{L}$ of CelLytic MT Mammalian (Sigma) with a protease-phosphatase inhibitor cocktail. Then the cells were cleared by centrifugation at 13,000 $\times \mathrm{g}$ at $4^{\circ} \mathrm{C}$ for 15 minutes, and protein concentration of the collected supernatant was analyzed with the ThermoScientific Bradford Assay protein kit.

Cell protein lysate samples were boiled to denaturate at $95^{\circ} \mathrm{C}$ in Laemmli Sample buffer with $\beta$-mercaptoethanol for 
7 minutes. A total of 15- $\mu$ g protein was used for Western blot analysis was performed with a total of $15-\mu \mathrm{g}$ protein.

\section{Western Blot Analysis and Antibodies}

$15 \mu \mathrm{L}$ cell protein lysate from each sample, including protein markers, were subjected to western blot BioRad Miniprotean Stain-Free TGX protein Gels, 4-15\%, 12-well comb, $20 \mu \mathrm{L}$, \#456-8085 within BioRad 1X Tris/Glycerine/SDS under a voltage of 250 for 20 minutes for electrophoresis, then immediately transferred to PVDF membranes which were kept in a $2.5 \%$ dry non-fat milk for one hour in TBS-T and co-incubated with the primary antibodies including antiADAMTS-1 (Abcam, Cambridge, UK. \#28284), anti-STAT3 [Santa Cruz Biotechnology, Inc. \#sc-482), anti-NF-kB (Santa Cruz Biotechnology, Inc. \#sc-372) and anti- $\beta$-actin (Santa Cruz Biotechnology, Inc. \#sc-69879) under $23^{\circ} \mathrm{C}$ for 16 hours. Membranes were washed with TBS-T three times for 10 minutes each at $23^{\circ} \mathrm{C}$, and then incubated with the secondary antibodies for one hour (Santa Cruz Biotechnology, Inc.) using HRP conjugation (1:2500) kit for one and a half hour at $23^{\circ} \mathrm{C}$ room temperature. Membranes were then washed for three times with TBS-T. Antibodies labeled with HRP were visualized with Immun-StarTM WesterCTM kits (BioRad, Australia) and BioRad ChemiDoc MP Imaging System. Image J software was used to analyze densitometry. The protein expression was quantified by normalized to the expression of $\beta$-actin.

\section{Statistical Analysis}

Data from the western blot assays were analyzed with the use of SPSS 21.0 software. All western blot bands were compared to the control group. Statistically significance of the density values was calculated using paired sample t-test. $p<0.05$ was regarded as results statistically significance. All the data are expressed as mean \pm SEM.

\section{RESULTS}

\section{Wound Migration Assay}

To estimate the migratory ability of PXA tumor cells, a wounding migration assay was conducted. The tumor cells were observed at different time points ( 24 and 48 hours after scratching) and treated with different IL-1 doses (10 and $30 \mathrm{ng} / \mathrm{mL}$ ). As shown in Figure 1A, PXA cells in the control group had not invaded the scratched area at the 24 and 48 hour timepoints. However, glioma cells were observed in the scratched area after 24 hours in both the 10 and $30 \mathrm{ng} / \mathrm{mL}$ IL-1 conditions. Migration increased significantly after 48 hours with both IL doses. The images were also evaluated with the WimScratch platform for proper quantification to provide unbiased results (Figure 1B). Twenty-four hours after scratching, the amount of PXA cells in the scratch significantly increased with the $10 \mathrm{ng} / \mathrm{mL} \mathrm{IL-1}$ dose compared to that of the no treatment control $(63.46 \%$ \pm 0.72 wound closure versus $79.7 \% \pm 0.7$, respectively, $\mathrm{p}=0.001$ ). Furthermore, 24 hours after scratching, the amount of PXA cells in the scratch significantly increased with the $30 \mathrm{ng} / \mathrm{mL} \mathrm{IL}-1$ dose compared to that of the control group, and no statistically significant difference was found in wound closure between the $10 \mathrm{ng} / \mathrm{mL}$ and $30 \mathrm{ng} / \mathrm{mL} \mathrm{IL-1}$ treatments at the 24 -hour timepoint $(80.3 \% \pm 1.00$ versus $79.7 \% \pm 0.7$, respectively, $p=0.184)$. When we observed the PXA cells in the scratched area at the 48 hour timepoint, the amount of cells in the scratch significantly increased, as compared to that at the 24-hour timepoint, with both IL-1 doses $(97.8 \% \pm 0.47$ versus $79.7 \% \pm 0.7$, respectively, in $10 \mathrm{ng} / \mathrm{mL} \mathrm{IL}-1 ; 99.6 \% \pm 0.15$ versus $80.3 \% \pm 1.00$, respectively, in $30 \mathrm{ng} / \mathrm{mL} \mathrm{IL}-1 ; \mathrm{p}=0.003$, $p=0.002$, respectively). No significant difference was found between 10 and $30 \mathrm{ng} / \mathrm{mL} \mathrm{IL-1}$ treatment doses at the 48 hour timepoint $(p=0.054)$ (Figure 2). From this, it can be concluded that IL-1 treatment provoked faster closure of the wound and migration increased over time.

\section{Western Blot}

The expression levels of ADAMTS-1, NF-kB, and STAT3 were detected by western blot analysis. ADAMTS- 1 was as a single $75 \mathrm{kDa}$ band, comparable to the expected size of the mature enzyme. NF-kB was seen as a single $65 \mathrm{kDa}$ band, and STAT3 as a single $86 \mathrm{kDa}$ band in lysate from PXA cells that received different treatments and at different timepoints. Fragments of ADAMTS-1 were not detected (visualized), and expression levels of ADAMTS-1, NF-kB, and STAT3 were expressed as the fold change.

ADAMTS-1, NF-kB, and STAT3 were found to be constitutively expressed in the treatment and non-treatment groups by western blotting of PXA cell lysates. Comparing the PXA cell lines treated with either 10 or $30 \mathrm{ng} / \mathrm{mL} \mathrm{IL}-1$, after 24 hours, the $10 \mathrm{ng} / \mathrm{mL} \mathrm{IL}-1$ treatment significantly increased the ADAMTS-1 expression levels to 1.86 fold higher and the 30 $\mathrm{ng} / \mathrm{mL}$ IL-1 treatment induced 1.94 fold increase compared to that of the non-treated control $(p=0.004$ and $p=0.005$, respectively) (Figure 3A). There were no significant differences in ADAMTS-1 expression levels between the 10 and $30 \mathrm{ng} / \mathrm{mL}$ IL-1 treatment groups $(p=0.067)$.

Moreover, the $10 \mathrm{ng} / \mathrm{mL} \mathrm{IL}-1$ induced an additional 1.6-fold upregulation in ADAMTS-1 gene expression in PXA cell lines after 48 hours as compared to the 24-hour timepoint. The $30 \mathrm{ng} / \mathrm{mL} \mathrm{IL}-1$ treatment induced an additional 1.68fold upregulation in ADAMTS-1 gene expression in PXA cell lines after 48 hours as compared to the 24-hour timepoint. ADAMTS- 1 expression levels after 48 hours, for both 10 and $30 \mathrm{ng} / \mathrm{mL}$ IL-1 treatments, were significantly higher than those after 24 hours ( $p=0.001$ and $p=0.004$, respectively) (Figure $3 \mathrm{~A})$. Significant difference in ADAMTS-1 expression was not detected between the 10 and $30 \mathrm{ng} / \mathrm{mL} \mathrm{IL-1}$ treatment groups after 48 hours $(p=0.047)$.

The $10 \mathrm{ng} / \mathrm{mL}$ and $30 \mathrm{ng} / \mathrm{mL} \mathrm{IL}-1$ treatments caused a 2.5 fold and 2.6 fold increase, respectively, in NF-kB protein levels in PXA cells after 24 hours when compared with the non-treatment group ( $p=0.025, p=0.005$; respectively). The levels of NF-kB were 1.52 and 1.57 fold higher after 48 hours than those at the 24-hour timepoint under IL-1 treatment of 10 and $30 \mathrm{ng} / \mathrm{mL}$, respectively, and were significantly different $(p=0.009$ and $p=0.005$, respectively) (Figure $3 B$ ). Significant difference was not found between the IL-1 10 and $30 \mathrm{ng} / \mathrm{mL}$ treatment groups at the 24 and 48 hour timepoints $(p=0.834$ and $p=0.092$, respectively). 

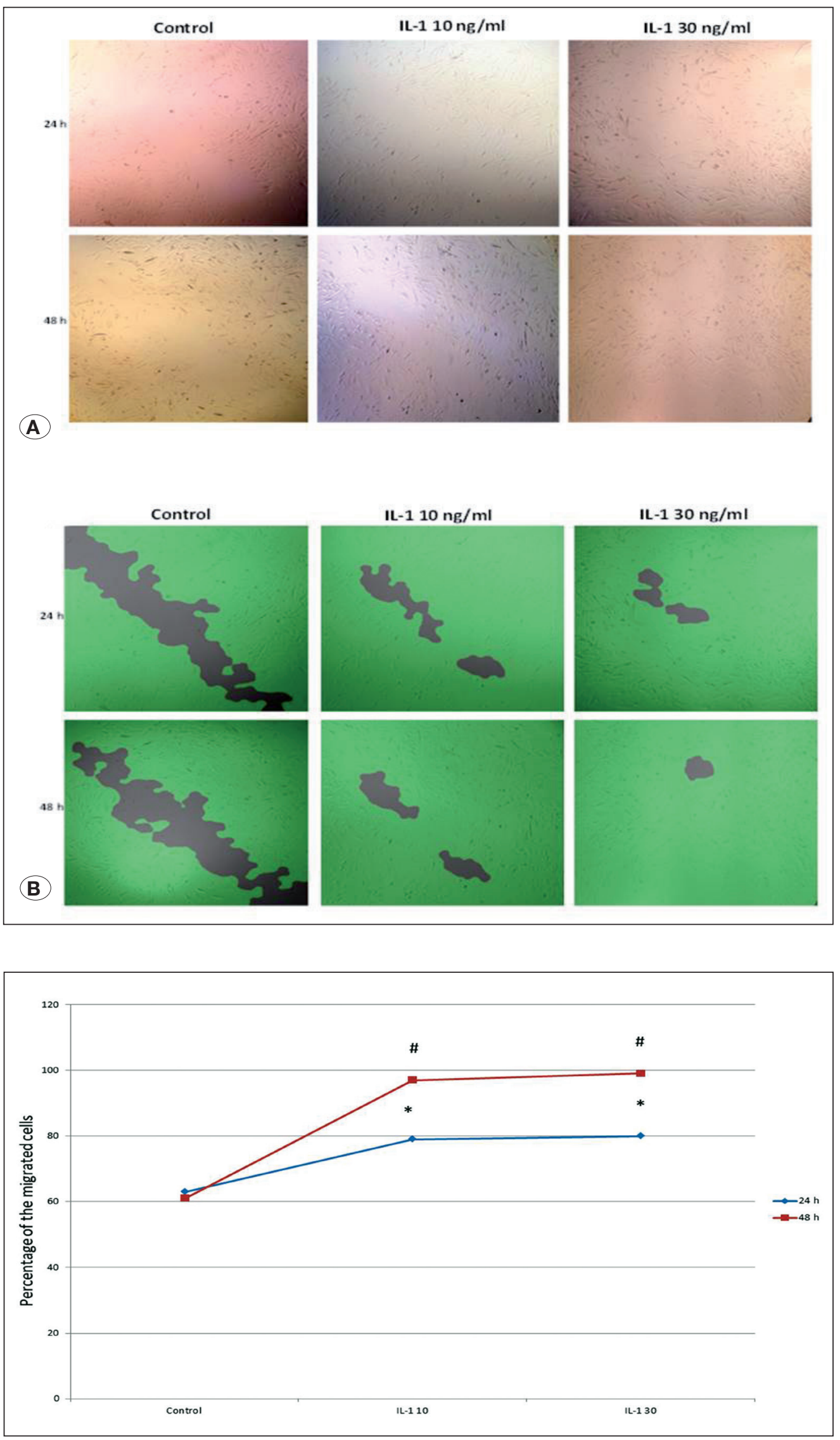

Figure 1: IL-1 effects on migration of pleomorphic xanthoastrocytoma. Cell migration was evaluated with the use of a wounding assay method. Pleomorphic xanthoastrocytoma cells were cultered with IL-1 $(0,10,30 \mathrm{ng} /$ $\mathrm{ml}$ ) for the time indicated. A) Wound healing assay showing the migrated PXA cells at 24 and 48 hours with and without treatment with IL-1 (10, $30 \mathrm{ng} / \mathrm{ml}$ ). B) Pictures of the computerized processing of images are shown in green by the WimScratch platform.
Figure 2: Graph show the precentage of the migrated cells resulted from the Wimscratch platform at 24 and 48 hours. ${ }^{*}$ Control versus 24 hours $(p<0.05)$, \# 24 hours versus 48 hours $(p<0.05)$. 
Similarly, $10 \mathrm{ng} / \mathrm{mL}$ and $30 \mathrm{ng} / \mathrm{mL}$ IL-1 treatment doses caused significant 2.62 fold and 2.43 fold increases, respectively, in STAT3 protein levels in PXA cells after 24 hours compared to that of the non-treatment control $(p=0.002, p=0.001$, respectively). The protein levels after 48 hours under 10 and 30 $\mathrm{ng} / \mathrm{mL} \mathrm{IL-1}$ doses were 1.44 and 1.57 fold higher, respectively, than those after 24 hours, and were significantly different $(p<0.001, p=0.001$, respectively) (Figure $3 C)$. No significant difference was found between the two treatment doses after 24 or 48 hours $(p=0.074, p=0.286$, respectively). All protein expression levels are outlined in Table I.

\section{DISCUSSION}

ADAMTS- 1 and its potential role was evaluated in the invasiveness of PXA, which is a rare brain tumor with a

Table I: The Protein Levels of ADAMTS-1, NFKB, and Stat3

\begin{tabular}{|c|c|c|c|c|c|c|}
\hline & $\begin{array}{l}\text { Control } \\
24 \text { hours }\end{array}$ & $\begin{array}{l}\text { Control } \\
48 \text { hours }\end{array}$ & $\begin{array}{l}\text { IL-1 } 10 \mathrm{ng} / \mathrm{mg} \\
24 \text { hours }\end{array}$ & $\begin{array}{c}\text { IL-1 } 30 \mathrm{ng} / \mathrm{ml} \\
24 \text { hours }\end{array}$ & $\begin{array}{l}\text { IL-1 } 10 \mathrm{ng} / \mathrm{ml} \\
48 \text { hours }\end{array}$ & $\begin{array}{l}\text { IL-1 } 30 \mathrm{ng} / \mathrm{ml} \\
48 \text { hours }\end{array}$ \\
\hline ADAMTS-1 & $0.36 \pm 0.01^{*, \dagger}$ & $0.36 \pm 0.02^{\ddagger, \S}$ & $0.68 \pm 0.01^{*, \pi}$ & $0.72 \pm 0.01^{\dagger, t \dagger}$ & $1.11 \pm 0.007^{\ddagger}, \pi$ & $1.21 \pm 0.01 \S,+\dagger$ \\
\hline NF-KB & $0.1 \pm 0.02^{*, \dagger}$ & $0.12 \pm 0.005^{\#, \S}$ & $0.25 \pm 0.006^{*, \pi}$ & $0.26 \pm 0.008^{t, t \dagger}$ & $0.38 \pm 0.005^{\#, q 1}$ & $0.41 \pm 0.003^{\S, t \dagger}$ \\
\hline Stat3 & $0.16 \pm 0.006^{*, \dagger}$ & $0.18 \pm 0.009 \neq, \S$ & $0.41 \pm 0.003^{\star, \star \star}$ & $0.39 \pm 0.005^{\dagger, t \dagger}$ & $0.71 \pm 0.003^{\ddagger, \star \star}$ & $0.72 \pm 0.009 \S,+\dagger$ \\
\hline
\end{tabular}

All data given as mean \pm SEM. ADAMTS: A Disintegrin and Metalloprotease with Trombospondin motifs, NF-кB: Nuclear factor -kappaB, Stat: Signal transducers and activators of transcription. *: Control $24 \mathrm{~h}$ vs IL-1 $10 \mathrm{ng} / \mathrm{ml} 24 \mathrm{~h}$ (p<0.05). t: Control $24 \mathrm{~h}$ vs IL-1 $30 \mathrm{ng} / \mathrm{ml} 24 \mathrm{~h}(\mathrm{p}<0.05)$. \#: Control $48 \mathrm{~h}$ vs IL-1 $10 \mathrm{ng} / \mathrm{ml} 48 \mathrm{~h}$ (p<0.001). \#: Control $48 \mathrm{~h}$ vs IL-1 $10 \mathrm{ng} / \mathrm{ml} 48 \mathrm{~h}$ (p<0.05). $\$$ : Control $48 \mathrm{~h}$ vs IL-1 $30 \mathrm{ng} / \mathrm{ml} 48 \mathrm{~h}(\mathrm{p}<0.05)$. 7: IL-1 $10 \mathrm{ng} / \mathrm{ml} 24 \mathrm{~h}$ vs IL-1 $10 \mathrm{ng} / \mathrm{ml} 48 \mathrm{~h}$ (p<0.05). **: IL-1 $10 \mathrm{ng} / \mathrm{ml} 24 \mathrm{~h}$ vs IL-1 $10 \mathrm{ng} / \mathrm{ml} 48 \mathrm{~h}$ (p<0.001). t†: IL-130 ng/ml 24 h vs IL-1 30 $n g / m l 48 h(p<0.05)$.

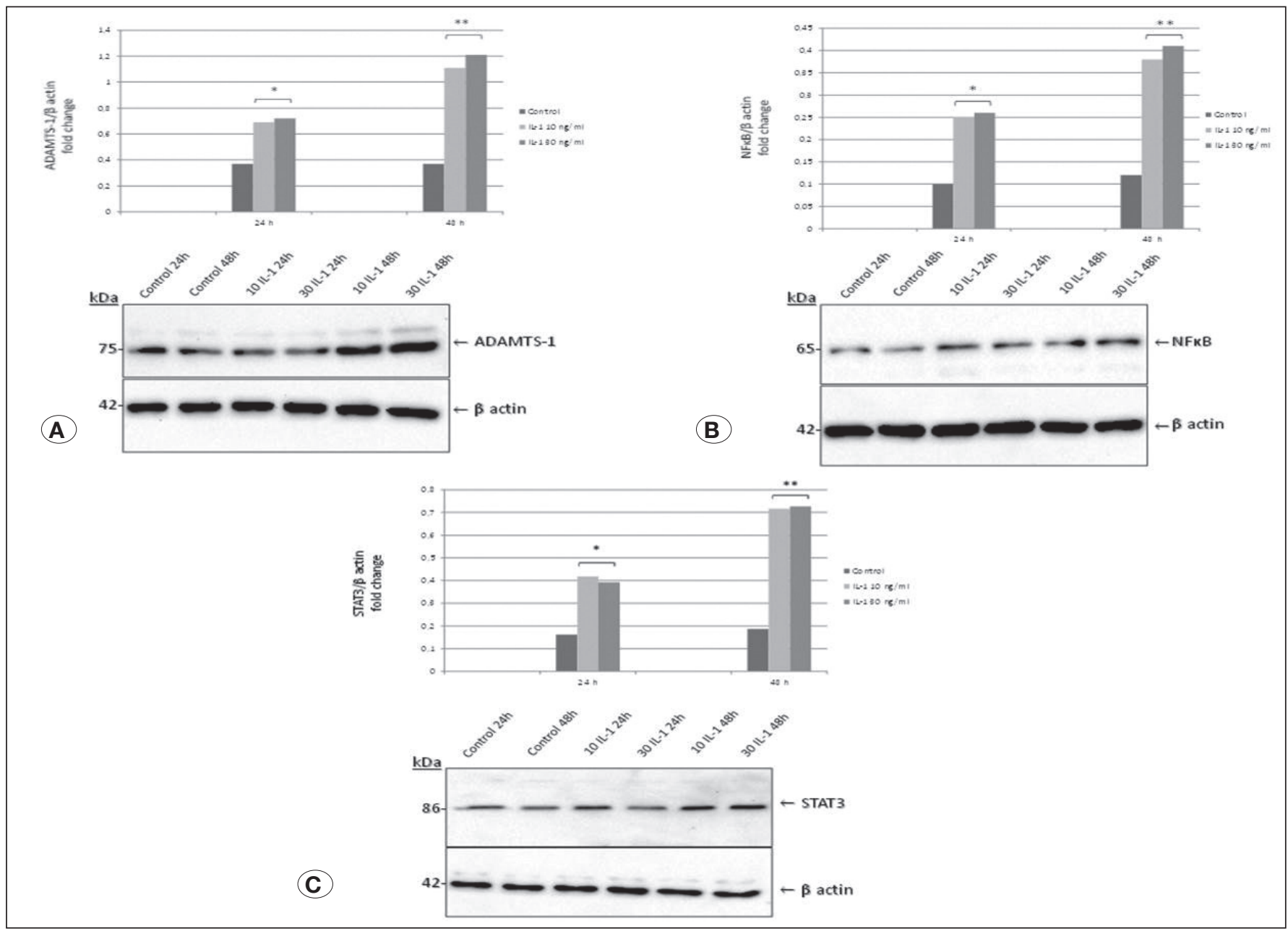

Figure 3: ADAMST-1 (A), NF-KB (B), and STAT3 (C) expression levels by Western blotting from 3 different experiments in PXA cell lines of control, 10 , and $30 \mathrm{ng} / \mathrm{ml} \mathrm{IL-1}$ treatment groups at 24 and 48 hours time points. The expression levels were expressed as the fold change. ${ }^{*}$ Control versus 24 hours $(p<0.05),{ }^{* *} 24$ hours versus 48 hours $(p<0.05)$. 
favorable prognosis compared to that of diffusely infiltrative astrocytomas. Moreover, we analyzed the expression levels of NF-KB and STAT3 under treatment with the cytokine IL-1. PXA cell lines were incubated with low- and high-dose IL-1 for 24 hours or 48 hours. To determine migration of cells and invasion, we performed a wound-healing assay. The present study is the first report to examine ADAMTS- 1 expression in PXA.

The migration, proliferation, and invasion of tumor cells increased under different doses of cytokine treatment, and aggressiveness increased significantly after 48 hours. Compatible with these findings, ADAMTS-1 was upregulated after cytokine treatment and significantly increased in activity after 48 hours. Similarly, the levels of NF-KB and STAT3 were concordant with the levels of ADAMTS- 1.

Among the 19 identified ADAMTS proteases, the first to be discovered, ADAMTS-1, has been shown to have catalytic activity on proteoglycans, including aggrecan, versican, and brevican $(22,23,37,45,47,58)$. Aggrecan is an ingredient of the brain ECM (59) and component of perineuronal nets (32). Brevican is also one of the main proteoglycans in adult brain (59). ADAMTS-1 (22), - 4 (18), and -5 (8) show the strongest aggrecanase activity. The degradation of proteoglycans by ADAMTS proteases has been shown to facilitate the invasion of surrounding normal brain tissues by glioma cells (36). In addition, the deregulation of ADAMTS- 1 is involved in migration, invasion, and tumor growth $(42,43)$. However, ADAMTS-1 has been known for its protumorigenic and antitumorigenic effects in different tumor types so the activities and contribution of ADAMTS-1 in tumorigenesis appears controversial $(13,29,52)$. Altered ADAMTS-1 expression levels have been reported to be lower in various tumors, such as gastric, hepatocellular, and breast cancers $(13,30,40,44)$. Several studies signify that the anti-tumoral activity of ADAMTS- 1 is likely due to its anti-angiogenic effect through its thrombospondin motifs via the inhibition of endothelial cell proliferation, independent of its protease activity $(38,54)$. However, higher ADAMTS-1 expression is often reported in primary gastric tumors with lymph node metastasis compared to that of primary gastric tumors (5). In addition, ADAMTS-1 is more highly expressed in breast and pancreatic cancers with the enhanced metastatic potential $(17,30)$. An elegant commentary about the diversity in differential expression levels of ADAMTS-1 in various tumors has been provided by Liu et al., revealing that full-length form of ADAMTS-1 display pro-tumor activity whereas $\mathrm{N}$ - or $\mathrm{C}$-terminal fragments generated by auto-proteolytic cleavage display potent anti-tumor activity (25). The pro-tumoral activity was shown to be regulated through the presence of a metalloproteinase domain (43).

There are several reports associating ADAMTS proteases are involved in progression of glioma mainly by the proteolytic activity on brevican and versican $(31,53,55)$. Recently, a report by Martino-Echarri et al. reported that high ADAMTS-1 regulation induces the proteolytic cleavage of Insulin-like Growth Factor Binding Protein 2 (IGFBP-2) in GBM to promote glioma invasion (28). Genomic studies by various groups assert that IGFBP-2 expression is a prognostic marker for the tumor grading of gliomas $(6,56)$. One report revealed that high expression levels of ADAMTS-1 and IGFBP-2 induce shorter survival times in glioma patients. Furthermore, Lo Cicero et al. (26) confirmed that oligodendroglioma cells express ADAMTS-1, - 4, and -5 , as has been previously shown in glioblastomas (15). Thus, overexpression of ADAMTS-1 might play an essential role in promoting tumor development and increasing the invasiveness of glioma cells.

We did not observe a persistent decrease in ADAMTS-1 levels proportional to the increase in PXA invasiveness compared with those of nonneoplastic tissue, as has been described in human breast carcinomas. IL-1 was found to increase ADAMTS-1 protein expression levels in PXA tumor cells until the termination of these studies after 48 hours. In agreement with previous findings, NF-KB and STAT3 expression levels were upregulated in the presence of IL-1 until the termination of these studies after 48 hours. NF-kB and STAT3 were chosen as potential transcription factors because they are known to be activated in glioma and collaborate to increase survival, proliferation, and tumor invasion and suppress anti tumor immunity via the activation of regulatory $T$ cells $(2,49,61)$. In addition, matrix metalloproteinase -2 and -9 expression is known to be directly upregulated by STAT-3 (16).

Although modulation of the ADAMTS genes is still not clear and not well understood, there is evidence that various factors, such as hormones, growth factors, and inflammatory cytokines, are involved in controlling their regulation (50). Rocks et al. reported that the transfection of human lung carcinoma BZR cells with full-length ADAMTS- 1 accelerated in vivo tumor growth in severe combined immunodeficient mice, and increased ADAMTS-1 expression seem to be associated with higher content of IL-1 and transforming growth factor $1 \beta$ (43). In addition, increased expression of ADAMTS-1 mRNA following hypoglossal nerve injury has been identified in N1E-115 rat cells treated with IL-1 (48). Cytokine expression in response to signals derived from glioma cells promote progression of glioma cells and modulate the recruitment and infiltration of immune cells (62). Our findings showed that increased ADAMTS-1 levels was related to IL-1 treatment of glioma cells.

\section{CONCLUSION}

Association between PXA and ADAMTS-1 proteases has never been postulated to date. In the present study, higher expression levels of ADAMTS-1 were detected in accordance with higher levels of NF-KB and STAT3 and increased invasiveness of PXA tumor cells. IL-1 stimulation may promote tumor progression, and ADAMTS-1, NF-kB, and STAT3 may be regulated in a way that favors the proliferation, invasiveness, and progression of tumor cells. Our findings about the role of ADAMTS- 1 in PXA tumor cells may provide a basis for future work. Because these results associating high expression levels of ADAMTS-1 with the invasiveness of PXA is based on in vitro data, further studies, including in vivo experimental studies, are needed to verify the role of ADAMTS-1 in PXA. Inhibiting the proteolytic function of ADAMTS- 1 mediated by IL-1 in gliomas may be a potential treatment to prevent malignant transformation of 
Gokce A. et al: ADAMTS-1 in Pleomorphic Xanthoastrocytoma

astrocytomas. Furthermore, the impact of IL-1 on low-grade gliomas must be carefully observed to identify the pathways related to cytokine stimulation.

\section{REFERENCES}

1. Abou-Ghazal M, Yang DS, Qiao W, Reina-Ortiz C, Wei J, Kong LY, Fuller GN, Hiraoka N, Priebe W, Sawaya R, Heimberger AB: The incidence, correlation with tumor-infiltrating inflammation, and prognosis of phosphorylated STAT3 expression in human gliomas. Clin Cancer Res 14:8228-8235, 2008

2. Brantley EC, Benveniste EN: Signal transducer and activator of transcription-3: A molecular hub for signaling pathways in gliomas. Mol Cancer Res 6:675-684, 2008

3. Brantley EC, Nabors LB, Gillespie GY, Choi YH, Palmer CA, Harrison K, Roarty K, Benveniste EN: Loss of protein inhibitors of activated STAT-3 expression in glioblastoma multiforme tumors: Implications for STAT-3 activation and gene expression. Clin Cancer Res 14:4694-4704, 2008

4. Bromberg JF, Wrzeszczynska MH, Devgan G, Zhao Y, Pestell RG, Albanese C, Darnell JE Jr: Stat3 as an oncogene. Cell 98:295-303, 1999

5. Chen J, Zhi Y, Chang X, Zhang S, Dai D: Expression of ADAMTS1 and its correlation with angiogenesis in primary gastric cancer and lymph node metastasis. Dig Dis Sci 58:405-413, 2013

6. Elmlinger $\mathrm{MW}$, Deininger $\mathrm{MH}$, Schuett BS, Meyermann R, Duffner F, Grote EH, Ranke MB: In vivo expression of insulin-like growth factor-binding protein-2 in human gliomas increases with the tumor grade. Endocrinology 142:16521658, 2001

7. Esselens C, Malapeira J, Colomé N, Casal C, RodríguezManzaneque JC, Canals F, Arribas J: The cleavage of semaphorin $3 \mathrm{C}$ induced by ADAMTS1 promotes cell migration. J Biol Chem 285:2463-2473, 2010

8. Gendron C, Kashiwagi M, Lim NH, Enghild JJ, Thøgersen IB, Hughes C, Caterson B, Nagase $\mathrm{H}$ : Proteolytic activities of human ADAMTS-5: Comparative studies with ADAMTS-4. J Biol Chem 282:18294-18306, 2007

9. Giannini C, Scheithauer BW, Burger PC, Brat DJ, Wollan PC, Lach B, O'Neill BP: Pleomorphic xanthoastrocytoma: What do we really know about it? Cancer 85:2033-2045, 1999

10. Goldbrunner RH, Bernstein JJ, Tonn JC: Cell-extracellular matrix interaction in glioma invasion. Acta Neurochir (Wien) 141:295-305, 1999

11. Grivennikov SI, Karin M: Dangerous liaisons. STAT3 and NF-kappaB collaboration and crosstalk in cancer. Cytokine Growth Factor Rev 21:11-19, 2010

12. Grivennikov SI, Karin M: Inflammation and oncogenesis: A vicious connection.Curr Opin Genet Dev 20:65-71, 2010

13. Gustavsson H, Wang W, Jennbacken K, Welén K, Damber JE: ADAMTS1, a putative anti-angiogenic factor, is decreased in human prostate cancer. BJU Int 104:1786-1790, 2009

14. Hatipoglu OF, Hirohata S, Yaykasli KO, Cilek MZ, Demircan K, Shinohata R, Yonezawa T, Oohashi T, Kusachi S, Ninomiya Y: The 3'-untranslated region of ADAMTS1 regulates its mRNA stability. Acta Med Okayama 63:79-85, 2009
15. Held-Feindt J, Paredes EB, Blömer U, Seidenbecher C, Stark AM, Mehdorn HM, Mentlein R: Matrix-degrading proteases ADAMTS4 and ADAMTS5 (disintegrins and metalloproteinases with thrombospondin motifs 4 and 5) are expressed in human glioblastomas. Int J Cancer 118:55-61, 2006

16. Huang S: Regulation of metastases by signal transducer and activator of transcription 3 signaling pathway: clinical implications. Clin Cancer Res 13:1362-1366, 2007

17. Kang Y, Siegel PM, Shu W, Drobnjak M, Kakonen SM, CordónCardo C, Guise TA, Massagué J: A multigenic program mediating breast cancer metastasis to bone. Cancer Cell 3:537-549, 2003

18. Kashiwagi M, Enghild JJ, Gendron C, Hughes C, Caterson B, Itoh Y, Nagase $\mathrm{H}$ : Altered proteolytic activities of ADAMTS-4 expressed by C-terminal processing. J Biol Chem 279:1010910119, 2004

19. Kaulich K, Blaschke B, Nümann A, von Deimling A, Wiestler OD, Weber RG, Reifenberger G: Genetic alterations commonly found in diffusely infiltrating cerebral gliomas are rare or absent in pleomorphic xanthoastrocytomas. J Neuropathol Exp Neurol 61:1092-1099, 2002

20. Kuno K, Kanada N, Nakashima E, Fujiki F, Ichimura F, Matsushima K: Molecular cloning of a gene encoding a new type of metalloproteinase-disintegrin family protein with thrombospondin motifs as an inflammation associated gene. J Biol Chem 272:556-562, 1997

21. Kuno K, Matsushima K: ADAMTS-1 protein anchors at the extracellular matrix through the thrombospondin type I motifs and its spacing region. J Biol Chem 273:13912-13917, 1998

22. Kuno K, Okada $Y$, Kawashima H, Nakamura H, Miyasaka $\mathrm{M}$, Ohno $\mathrm{H}$, Matsushima K: ADAMTS-1 cleaves a cartilage proteoglycan, aggrecan. FEBS Lett 478:241-245, 2000

23. Kuno K, Terashima $\mathrm{Y}$, Matsushima K: ADAMTS-1 is an active metalloproteinase associated with the extracellular matrix. J Biol Chem 274:18821-18826, 1999

24. Le Bras GF, Taylor C, Koumangoye RB, Revetta F, Loomans HA, Andl CD: TGF $\beta$ loss activates ADAMTS-1-mediated EGFdependent invasion in a model of esophageal cell invasion. Exp Cell Res 330:29-42, 2015

25. Liu YJ, Xu Y, Yu Q: Full-length ADAMTS-1 and the ADAMTS-1 fragments display pro- and antimetastatic activity, respectively. Oncogene 25:2452-2467, 2006

26. Lo Cicero A, Majkowska I, Nagase H, Di Liegro I, Troeberg L: Microvesicles shed by oligodendroglioma cells and rheumatoid synovial fibroblasts contain aggrecanase activity. Matrix Biol 31:229-233, 2012

27. Lo HW, Cao X, Zhu H, Ali-Osman F: Constitutively activated STAT3 frequently coexpresses with epidermal growth factor receptor in high-grade gliomas and targeting STAT3 sensitizes them to Iressa and alkylators. Clin Cancer Res 14:6042-6054, 2008

28. Martino-Echarri E, Fernández-Rodríguez R, Bech-Serra JJ, Plaza-Calonge Mdel C, Vidal N, Casal C, Colomé N, Seoane J, Canals F, Rodríguez-Manzaneque JC: Relevance of IGFBP2 proteolysis in glioma and contribution of the extracellular protease ADAMTS1. Oncotarget 5:4295-4304, 2014 
29. Martino-Echarri E, Fernández-Rodríguez R, RodríguezBaena FJ, Barrientos-Durán A, Torres-Collado AX, PlazaCalonge Mdel C, Amador-Cubero S, Cortés J, Reynolds LE, Hodivala-Dilke KM, Rodríguez-Manzaneque JC: Contribution of ADAMTS1 as a tumor suppressor gene in human breast carcinoma. Linking its tumor inhibitory properties to its proteolytic activity on nidogen-1 and nidogen-2. Int $\mathrm{J}$ Cancer 133: 2315-2324, 2013

30. Masui T, Hosotani R, Tsuji S, Miyamoto Y, Yasuda S, Ida J, Nakajima S, Kawaguchi M, Kobayashi H, Koizumi M, Toyoda E, Tulachan S, Arii S, Doi R, Imamura M: Expression of METH1 and METH-2 in pancreatic cancer. Clin Cancer Res 7:34373443,2001

31. Matthews RT, Gary SC, Zerillo C, Pratta M, Solomon K, Arner EC, Hockfield S: Brain-enriched hyaluronan binding $(\mathrm{BEHAB}) /$ brevican cleavage in a glioma cell line is mediated by a disintegrin and metalloproteinase with thrombospondin motifs (ADAMTS) family member. J Biol Chem 275:2269522703, 2000

32. Matthews RT, Kelly GM, Zerillo CA, Gray G, Tiemeyer M, Hockfield S: Aggrecan glycoforms contribute to the molecular heterogeneity of perineuronal nets. J Neurosci 22:7536-7547, 2002

33. McFarland BC, Hong SW, Rajbhandari R, Twitty GB Jr, Gray GK, Yu H, Benveniste EN, Nozell SE: NF-kB-induced IL-6 ensures STAT3 activation and tumor aggressiveness in glioblastoma. PLoS One 8:e78728, 2013

34. Mut M, Amos S, Hussaini IM: PKC alpha phosphorylates cytosolic NF-kappaB/p65 and PKC delta delays nuclear translocation of NF-kappaB/p65 in U1242 glioblastoma cells. Turk Neurosurg 20:277-285, 2010

35. Nagase $H$, Kashiwagi M: Aggrecanases and cartilage matrix degradation. Arthritis Res Ther 5:94-103, 2003

36. Nakada M, Miyamori H, Kita D, Takahashi T, Yamashita J, Sato H, Miura R, Yamaguchi Y, Okada Y:Human glioblastomas overexpress ADAMTS-5 that degrades brevican. Acta Neuropathol 110:239-246, 2005

37. Nakamura H, Fujii Y, Inoki I, Sugimoto K, Tanzawa K, Matsuki $H$, Miura R, Yamaguchi $Y$, Okada Y: Brevican is degraded by matrix metalloproteinases and aggrecanase-1 (ADAMTS4) at different sites. J Biol Chem 275:38885-38890, 2000

38. Obika M, Ogawa H, Takahashi K, Li J, Hatipoglu OF, Cilek MZ, Miyoshi T, Inagaki J, Ohtsuki T, Kusachi S, Ninomiya Y, Hirohata S: Tumor growth inhibitory effect of ADAMTS1 is accompanied by the inhibition of tumor angiogenesis. Cancer Sci 103:1889-1897, 2012

39. Perkins SM, Mitra N, Fei W, Shinohara ET: Patterns of care and outcomes of patients with pleomorphic xanthoastrocytoma: A SEER analysis. J Neurooncol 110:99-104, 2012

40. Porter S, Scott SD, Sassoon EM, Williams MR, Jones JL, Girling AC, Ball RY, Edwards DR: Dysregulated expression of adamalysin-thrombospondin genes in human breast carcinoma. Clin Cancer Res 10:2429-2940, 2004

41. Prasad S, Ravindran J, Aggarwal BB: NF-kappaB and cancer: How intimate is this relationship. Mol Cell Biochem 336:25-37, 2010
42. Rocks N, Paulissen G, El Hour M, Quesada F, Crahay C, Gueders M, Foidart JM, Noel A, Cataldo D: Emerging roles of ADAM and ADAMTS metalloproteinases in cancer. Biochimie 90:369-379, 2008

43. Rocks N, Paulissen G, Quesada-Calvo F, Munaut C, Gonzalez ML, Gueders M, Hacha J, Gilles C, Foidart JM, Noel A, Cataldo DD: ADAMTS-1 metalloproteinase promotes tumor development through the induction of a stromal reaction in vivo. Cancer Res 68:9541-9550, 2008

44. Rocks N, Paulissen G, Quesada Calvo F, Polette M, Gueders M, Munaut C, Foidart JM, Noel A, Birembaut P, Cataldo D: Expression of a disintegrin and metalloprotease (ADAM and ADAMTS) enzymes in human non-small-cell lung carcinomas (NSCLC). Br J Cancer 94:724-730, 2006

45. Rodríguez-Manzaneque JC, Westling J, Thai SN, Luque A, Knauper V, Murphy G, Sandy JD, Iruela-Arispe ML: ADAMTS1 cleaves aggrecan at multiple sites and is differentially inhibited by metalloproteinase inhibitors. Biochem Biophys Res Commun 293:501-508, 2002

46. Russell DL, Doyle KM, Ochsner SA, Sandy JD, Richards JS: Processing and localization of ADAMTS-1 and proteolytic cleavage of versican during cumulus matrix expansion and ovulation. J Biol Chem 278 42330-42339, 2003

47. Sandy JD, Westling J, Kenagy RD, Iruela-Arispe ML, Verscharen C, Rodriguez-Mazaneque JC, Zimmermann DR, Lemire JM, Fischer JW, Wight TN, Clowes AW: Versican V1 proteolysis in human aorta in vivo occurs at the Glu441-Ala442 bond, a site that is cleaved by recombinant ADAMTS- 1 and ADAMTS-4. J Biol Chem 276:13372-13378, 2001

48. Sasaki M, Seo-Kiryu S, Kato R, Kita S, Kiyama H: A disintegrin and metalloprotease with thrombospondin type1 motifs (ADAMTS-1) and IL-1 receptor type 1 mRNAs are simultaneously induced in nerve injured motor neurons. Brain Res Mol Brain Res 89:158-163, 2001

49. Senft C, Priester M, Polacin M, Schröder K, Seifert V, Kögel D, Weissenberger J: Inhibition of the JAK-2/STAT3 signaling pathway impedes the migratory and invasive potential of human glioblastoma cells. J Neurooncol 101:393-403, 2011

50. Turner SL, Blair-Zajdel ME, Bunning RA: ADAMs and ADAMTSs in cancer. Br J Biomed Sci 66:117-128, 2009

51. Turner SL, Mangnall D, Bird NC, Bunning RA, Blair-Zajdel ME: Expression of ADAMTS-1, ADAMTS-4, ADAMTS-5 and TIMP3 by hepatocellular carcinoma cell lines. Int $\mathrm{J}$ Oncol 41:1043-1049, 2012

52. Tyan SW, Hsu CH, Peng KL, Chen CC, Kuo WH, Lee EY, Shew JY, Chang KJ, Juan LJ, Lee WH: Breast cancer cells induce stromal fibroblasts to secrete ADAMTS1 for cancer invasion through an epigenetic change. PLoS One 7:e35128, 2012

53. Varga I, Hutóczki G, Szemcsák CD, Zahuczky G, Tóth J, Adamecz Z, Kenyeres A, Bognár L, Hanzély Z, Klekner A: Brevican, neurocan, tenascin- $C$ and versican are mainly responsible for the invasiveness of low-grade astrocytoma. Pathol Oncol Res 18:413-420, 2012

54. Vázquez $F$, Hastings $G$, Ortega MA, Lane TF, Oikemus S, Lombardo M, Iruela-Arispe ML: METH-1, a human ortholog of ADAMTS-1, and METH-2 are members of a new family of proteins with angio-inhibitory activity. J Biol Chem 274: 23349-23357, 1999 
55. Viapiano MS, Hockfield S, Matthews RT: BEHAB/brevican requires ADAMTS-mediated proteolytic cleavage to promote glioma invasion. J Neurooncol 88:261-272, 2008

56. Wang $H$, Wang $H$, Shen $W$, Huang $H$, Hu L, Ramdas L, Zhou YH, Liao WS, Fuller GN, Zhang W: Insulin-like growth factor binding protein 2 enhances glioblastoma invasion by activating invasion-enhancing genes. Cancer Res 63:43154321, 2003

57. Werb Z: ECM and cell surface proteolysis: Regulating cellular ecology. Cell 91:439-442, 1997

58. Westling J, Gottschall PE, Thompson VP, Cockburn A, Perides G, Zimmermann DR, Sandy JD: ADAMTS4 (aggrecanase-1) cleaves human brain versican V2 at Glu405-GIn406 to generate glial hyaluronate binding protein. Biochem J 377:787-795, 2004
59. Yamaguchi Y: Lecticans: Organizers of the brain extracellular matrix. Cell Mol Life Sci 57:276-289, 2000

60. Yu H, Jove R: The STATs of cancer-new molecular targets come of age. Nat Rev Cancer 4:97-105, 2004

61. Yu H, Pardoll D, Jove R: STATs in cancer inflammation and immunity: A leading role for STAT3. Nat Rev Cancer 9:798809, 2009

62. Zhu VF, Yang J, Lebrun DG, Li M: Understanding the role of cytokines in Glioblastoma Multiforme pathogenesis. Cancer Lett 316(2):139-150, 2012 